\title{
Paideusis
}

\section{Ethical Habituation and Pleasure}

\section{Paul O'Leary}

Volume 16, Number 1, 2007

URI: https://id.erudit.org/iderudit/1072605ar

DOI: https://doi.org/10.7202/1072605ar

See table of contents

Publisher(s)

Canadian Philosophy of Education Society

ISSN

0838-4517 (print)

1916-0348 (digital)

Explore this journal

Cite this article

O'Leary, P. (2007). Ethical Habituation and Pleasure. Paideusis, 16(1), 41-45. https://doi.org/10.7202/1072605ar
Article abstract

Is it possible for a person to acquire virtues of character solely by reading books and/or attending lectures on ethical theory? According to Aristotle, no ethical theory, no matter how well formed and powerful, can eliminate the need for a well conducted ethical habituation. One element that allows such an habituation to play a significant role in the acquisition of the virtues is the link between virtue and pleasure. In short, no ethical theory can, on its own, provide a moral education since it cannot generate the experience of pleasure found in one who lives the life of the virtues.
This document is protected by copyright law. Use of the services of Erudit (including reproduction) is subject to its terms and conditions, which can be viewed online.

https://apropos.erudit.org/en/users/policy-on-use/ 


\title{
Ethical Habituation and Pleasure
}

\author{
PAUL O'LEARY \\ University of Western Ontario, Canada
}

\begin{abstract}
Is it possible for a person to acquire virtues of character solely by reading books and/or attending lectures on ethical theory? According to Aristotle, no ethical theory, no matter how well formed and powerful, can eliminate the need for a well conducted etbical habituation. One element that allows such an habituation to play a significant role in the acquisition of the virtues is the link. between virtue and pleasure. In short, no ethical theory can, on its own, provide a moral education since it cannot generate the experience of pleasure found in one who lives the life of the virtues. ${ }^{1}$
\end{abstract}

Given the revival of a neo-Aristotelian approach to moral education, an emphasis on ethical habituation should come as no surprise. Unsurprising too is the connection between education and pleasure. After all, Aristotle does write that "we must have been brought up in a certain way from childhood onwards, as Plato says, so as to delight in and be distressed by the things we should; this is what the correct education is." 2 As further support for connecting education with pleasure and distress, Aristotle notes that we often resort to "the practice of forcible correction which takes place through pleasure and pain" (NE 1104b, 16-17). But is the significance of pleasure within education to be restricted to its role as a corrective device? As correctives, pleasure and distress are used not only to encourage certain types of conduct, but also to foster certain affective dispositions. ${ }^{3}$ Moreover, in correcting a young person's conduct and feelings, pleasure and distress are not limited to being rewards and punishments. So, for example, a parent can correct a child's conduct and/or feelings in a nonpunitive manner by displaying pleasure or distress when a child acts well or badly. Correction, however, is not the only use that pleasure and distress can have in the upbringing of the young. For in addition to regarding pleasure and pain as correctives, Aristotle writes that the "pleasure or pain that supervenes on what people do should be treated as a sign of their dispositions" (NE 1104b, 1). In this paper I consider this aspect of the role of pleasure within education since it seems to me to be something of a neglected topic within the philosophy of education. As we shall see, viewing pleasure in this way gives it a significance for the educator which treating pleasure as a corrective device cannot have. However, pleasure as a symptom of an agent's dispositions has a problematic aspect which needs to be considered before its connection with virtue can be regarded as entirely credible.

\footnotetext{
1 Similar things can be said about classroom discussions of moral dilemmas. Without a well-conducted ethical habituation, relying on discussion alone might produce cleverness but not an excellent ethical disposition.

2 Aristotle, Nicomachean Ethics, trans. Christopher Rowe, 1104b 11-13 (hereafter cited in text as NE).

3 On the use of pleasure and distress in shaping the affective dispositions see Jan Steutel and Ben Spieker "Cultivating Sentimental Dispositions Through Aristotelian Habituation."

(C) Copyright 2007. The author, Paul O'Leary, assigns to Paideusis the right of first publication and educational and non-profit institutions a non-exclusive license to use this document for personal use and in courses of instruction provided that the article is used in full and this copyright statement is reproduced. Any other usage is probibited without the express permission of the author.
} 


\section{II}

The dual role of pleasure, as either a corrective or a symptom, points to a dual function in the role of the educator. As a corrective, pleasure allows a teacher to provide an incentive for students to act as a virtue requires. But as a symptom, pleasure provides an educator with one significant means by which to determine whether a virtuous disposition has been established. However, what a teacher needs in order to interpret success or failure in the fostering of the virtues rests upon certain features which characterize a transformation within the one being educated. In order to consider what is involved in such a transformation, let us consider some examples.

Suppose a parent says to a child, "Stop picking your nose! It's a disgusting habit." The child complies but his or her reason for doing so is fear of the parent's wrath. In this case, the reason for compliance is the avoidance of the distress characteristically involved in fear of punishment. But now consider pleasure as a symptom of a virtue having been established. Suppose for example, I turn down that third glass of a delicious Châteauneuf du Pape, and do so without resentment or struggle. When asked by my surprised host why I didn't want more, I reply, "Oh, I think I've had enough, thank you." Notice however that, in this case, my reason for doing so is not to avoid the distress of a hangover, however slight, but rather is internally related to the virtue of temperance. To turn down something because it would be "too much" is to give a reason which is characteristic of a temperate person.

One point of these examples is to draw attention to a transformation which can take place within an agent. Such a transformation is in terms of his or her reasons for action. But now consider what an educator needs to make a judgement about whether a virtuous disposition has been established. First of all, he or she could not make such a judgement solely on the basis of an agent's actions. After all, someone without a shred of temperance may act as that virtue requires, but does so by mistake. But suppose our non-temperate agent knows what he or she is doing and follows Hamlet's advice by "pretending to virtue though he have it not". Perhaps he or she knowingly acts as a temperate person and turns down that third glass of wine, not because it would be "too much," but because doing so would raise his or her esteem in the eyes of others. Thus the educator, in judging whether a virtue has been established, not only has to determine whether an agent knowingly acts as that virtue requires, but also needs to recognize the sort of reasons from which the agent acts. Would it not suffice then, in order to judge whether a virtue has been established, to do so in terms of actions knowingly done from reasons characteristic of a virtue? Why add pleasure?

Two points need to be made about pleasure and its connection with virtue. First, pleasure and its opposite distress, supervene in all the areas of human life where the virtues and vices apply. So then, the dispositions that form an agent's character find their application in such areas as facing danger, dealing with physical pleasure, getting and dispensing wealth, receiving honours, as well as engaging in social relationships. Of course, the notion of pleasure and distress connected with virtue and vice is not identical to physical pleasure since one can take pleasure in having a conversation with a friend as well as feeling distress in not receiving a promotion. So virtues of character, as dispositions of character to act well in each of the areas of human life on the basis of relevant reasons, function co-extensively with feelings of pleasure and distress. Connecting pleasure and distress as symptomatic of dispositions of character is far from being arbitrary. Secondly, as symptoms, pleasure and distress tell us something about the condition of an agent in a manner analogous to the way in which medical symptoms tell us something about the health of the patient. Resorting once again to the example of temperance, suppose an educator has evidence that, although someone acts knowingly as the temperate person would act and does so on the basis of reasons characteristic of temperance, yet detects that the agent is acting with a certain amount of reluctance. This reluctance, as a form of distress, signals to the educator that the agent is in conflict with himself or herself. Or, as Michael Stocker puts it, such an agent is in a 
condition of moral schizophrenia. ${ }^{4}$ The distress which is felt on the part of such a agent is a symptom of that agent's desire to act in ways contrary to what that very same agent also acknowledges as the reasonable way to act. In such cases of inner conflict, if the agent overcomes temptation and acts as his or her reasons require, then such a person is merely continent. If, however, such a conflicted person yields to temptation and acts contrary to what he or she acknowledges to be good and sufficient reasons to act, then we have an akratic. However, if one takes pleasure in acting for virtue related reasons, this is symptomatic of a harmony between that agent's inclinations and reasons. Of course, pleasure as symptomatic of a harmony between an agent's inclinations and reasons cannot alone reveal that such a person is in an excellent ethical condition. After all, a perfectly vicious person may take pleasure in acting as his or her vices dictate. So in addition to noting the pleasure displayed by someone in his or her actions, an educator also needs to know what an agent knowingly does and for what reasons. Although pleasure as a symptom of the ethical condition of an agent does not, by itself, indicate that a virtuous disposition has been established, it nonetheless retains its significance for an educator. For it, in conjunction with other symptoms, helps the educator sort out who is in excellent ethical condition and who is merely continent or akratic.

\section{III}

Assuming then, that pleasure as a symptom of a virtuous disposition has some initial credibility, how could the transformation of pleasure from being a reason to being a symptom be effected? Consider once again our nose picking child. While the example emphasizes reasons connected with the avoidance of the pain of punishment, it could also be the case that the child complies with the parent's wishes so as not to be distressed over the parent's distress triggered by his or her non-compliance. When a child begins to consider what to do, not only in terms of what pleases or distresses him or her, but also in terms of what pleases or distresses others, then a relatively primitive form of ethical life is beginning to take place. The transformation of the child from being an amoral hedonist into someone for whom ethical considerations begin to weigh, is effected, not by presenting someone with a well thought out theory of why ethical considerations matter, but is more likely to begin through the attachment one person has for another. It is because a child cares about his or her parent, no matter how inchoate that care may be, that ethical considerations begin to get a grip on a child's motivation. ${ }^{5}$

A child's particular attachment to someone else is only the starting point at which ethical considerations begin to count for him or her. Whereas a child's generosity, for example, may extend only to those for whom he or she has feelings of attachment, a person who has a developed sense of generosity may act as that virtue requires towards those for whom he or she has no particular feelings at all; he or she neither likes nor dislikes them but helps them because they need something and he or she is in a position to aid them. In this picture of acquiring the virtues, agents move from being amoral hedonists to being those who act as the virtues require and for reasons which are internally connected to the virtues. When this point is reached, pleasure and distress do not enter as reasons for acting. Since the agent's reasons are virtue related, the pleasure or distress experienced by the agent is symptomatic of stable features of his or her character.

This picture of acquiring the virtues as involving a transformation of pleasure from being a reason to being a symptom is, however, clouded by the fact that the nature of the pleasure involved remains problematic. For the amoral hedonist "because I enjoy it" remains the only and sufficient reason for doing something. That, at least, is intelligible. But to regard a courageous soldier on the battlefield, facing the real possibility of being either killed or maimed, as enjoying himself or herself, is,

\footnotetext{
4 "The Schizophrenia of Modern Ethical Theories." I want to thank one of the referees of this paper for this reference.

${ }^{5}$ See Bernard Williams, Morality, Chapter One.
} 
to say the least, stretching credulity. Yet if he or she remains steadfast in the face of the terror and chaos of the battlefield and acts boldly for a cause which is noble, then he or she is courageous.

The problematic nature of the connection between virtue and pleasure is not confined to a virtue such as courage. Similar difficulties are to be found in virtues such a justice and truthfulness. Consider, for example, a teacher who gives a student a well deserved failing grade, while also telling that student some rather unpleasant truths. Only a sadist would enjoy doing these things, even though justice and truthfulness may call for these actions. So then if we are to connect pleasure as a symptom of the presence of a virtue, we need to give a characterization of pleasure which restores its connection with virtue without sacrificing credibility.

\section{IV}

Experiencing pleasure may assume various forms, enjoyment being only one of them. We can, for example, take pleasure in something by being pleased by it, liking it, being delighted by it, finding it satisfying, rejoicing in it, being absorbed by it, being amused by it, or being glad of it. No doubt these are not the only ways in which pleasure may be experienced, nor does any one of them fit all cases of pleasure. The question is whether any of these forms of pleasure can credibly be symptomatic of the presence of a virtue.

It does not stretch credulity to say that it is symptomatic of a virtuous person to act willingly, unreluctently and ungrudgingly. These adverbial modifications in the descriptions of how a virtuous person acts suggest that the corresponding pleasure, involved in acting as virtue requires, should also reflect the manner in which the action is done. Characterizing an agent as gladly acting as virtue requires does this more credibly than saying that he or she enjoys so acting.

Although credulity suffers when we view a courageous soldier as enjoying placing his or her life in danger, credibility in the connection between virtue and pleasure can be maintained if we regard a soldier as courageous when he or she gladly risks his or her life in a cause which is worthwhile. Likewise, it is hardly absurd to say of that soldier, when he or she is engaged in recalling the past, that he or she has no regrets and is indeed glad of what was done. However, unless there is a love of fighting, it would be a stretch of the imagination to say that that soldier enjoyed participating in battle.

Although pleasure, understood as acting gladly, can restore some intelligibility to the connection between virtue and pleasure, there is a possible awkwardness arising from the way in which an action gladly done is characterized. Consider once again the teacher who gives a student a justly deserved failing grade while also telling that student some unpleasant truths. If we say that the teacher gladly failed the student while also telling some harrowing truths, then he or she would appear to be as sadistic as one who enjoyed doing these things. This, however, is to view these actions independently of the value of the aims which the teacher is seeking to achieve. In the example of the soldier, gladly risking life and limb would be nothing more than foolhardiness except for the fact that the cause for which he or she is fighting is worthwhile. Similar things can be said about the teacher. What lifts his or her actions from being an instance of cruelty to being a case of fairness and truthfulness, is his or her goal of getting students to make an accurate self-assessment of their abilities. In aiming at this, the teacher is acting virtuously rather than viciously. What the teacher gladly does is to help that student rather than humiliate him or her. The connection between virtue and pleasure, in at least one of its forms, is still a credible one.

Just as enjoying a walk adds something to simply taking a walk, gladly acting as virtue requires also adds something to simply acting as virtue requires. But what can this additional element be? What I think is characteristic of one who gladly acts as virtue requires is that he or she wholeheartedly, vigorously, and successfully lives the sort of life required by the virtues. What is absent in the person who acts according to the virtues, albeit reluctantly, is just this wholehearted attachment to the sort of life which exemplifies the virtues. Once again, we should remind ourselves that a wholehearted 
attachment to a certain way of life can also characterize a person who is thoroughly vicious and who therefore gladly does what is characteristic of one or several vices. Wholeheartedness does not distinguish between virtue and vice, but rather between acts done gladly from a stable disposition and those which are done simply because they are required. Even vicious acts can be done either gladly or reluctantly.

\section{V}

Suppose we return to the earlier picture of moral education as involving a transformation of pleasure from being a reason for acting to being a symptom of the virtues. This requires transforming the agent from one for whom "I enjoy it" is always a reason for acting to one who gladly does as virtue requires where the reasons for acting are related to one or another particular virtue. Thus an honest person will gladly avoid falsifying tax returns, not because he or she enjoys not cheating, but because falsification is an instance of cheating. But given what constitutes the difference between gladly acting as virtue requires and just acting that way, acquiring the virtues involves transforming an amoral hedonist into someone who has a wholehearted attachment to the sort of life which exemplifies the virtues-by no means an easy task.

In the beginning of this essay I asked why a person could not acquire the virtues solely by attending to ethical theories. Even if these theories turn out to be very convincing and persuade others that the life of the virtues is the best sort of life for humans to lead, they will not suffice since a wholehearted attachment to such a life is not simply a matter of intellectual conviction. Of course, what place any ethical theory can occupy within moral education is another story.

\section{References}

Aristotle. The Nicomachean Ethics. Translated with historical introduction by Christopher Rowe. Philosophical introduction and commentary by Sarah Broadie. New York: Oxford University Press, 2000.

Steutel, Jan, and Ben Spieker. "Cultivating Sentimental Dispositions Through Aristotelian Habituation." Journal of the Philosophy of Education 38, no. 4 (November 2004): 531-549.

Stocker, Michael. "The Schizophrenia of Modern Ethical Theories." In Virtue Ethics, edited by Roger Crisp and Michael Slote, 66-78. New York: Oxford University Press, 1997.

Williams, Bernard. Morality. Cambridge: Cambridge University Press, 1972.

\section{About the Author}

Paul O'Leary is a professor emeritus at the University of Western Ontario. He has published articles in such journals as The Transactions of the Charles S. Peirce Society, Educational Theory, Canadian Journal of Education and Paideusis. He is currently investigating virtue-based moral education as well as the connection between teaching and the ethics of belief. 